\title{
GEREJA DAN TRANSFORMASI KRISTEN SUATU TINJAUAN KRITIS TERHADAP MISI GERAKAN TRANSFORMASI
}

\author{
RIDWAN HENRY SIMAMORA
}

\begin{abstract}
PENDAHULUAN
Istilah transformasi beberapa tahun belakangan ini menjadi isu yang menarik dalam konteks kehidupan berbangsa dan Negara pada umumnya serta relasinya dalam pemikiran kehidupan Kristen atau Gereja khususnya. Transformasi menjadi tema penting yang tidak hanya dipikirkan, tetapi juga diusahakan dalam pergerakannya secara serius oleh beberapa kelompok tertentu. Pada Gereja-gereja tertentu di Indonesia istilah "transformasi" demikian marak dibicarakan dan dikhotbahkan pada mimbar-mimbar Gereja, bahkan terkesan upaya tersebut mengkristal sebagai sebuah gerakan dalam upaya mengubah masyarakat dan Negara, serta upaya yang serius untuk menjadikan transformasi sebuah tema nasional dalam berbangsa dan bernegara umumnya dan dalam konteks Gereja khususnya. Satu sisi, fenomena tersebut adalah positif, karena gerakan tersebut sebagai upaya memfasilitasi proses upaya persatuan berbagai denominasi Gereja-gereja di Indonesia, seperti yang terjadi pada helatan akbar National Prayer Conference (NPC) pada tahun 2003, walaupun pada saat itu NPC tidak langsung dapat diterima oleh seluruh Gereja-gereja di Indonesia, serta World Prayer Assembly (WPA) yang telah digelar pada bulan Mei 2012 lalu secara serentak di seluruh Indonesia. Namun pada sisi lain, ada indikasi gerakan ini bercampurbaur dengan spirit yang beraroma persaingan "perebutan kekuasaan," suatu upaya menjadikan orang Kristen sebagai mayoritas melalui penginjilan atau dengan bahasa yang lebih tepat sebagai usaha mengkristenkan Indonesia serta mencalonkan tokoh Kristen sebagai pemimpin negara. Jika asumsi ini tepat, maka transformasi telah diartikan secara bias.

Istilah transformasi dalam bahasa Kristen dan dalam konteks Indonesia bukanlah suatu istilah yang asing dan acapkali menjadi bahan pembicaraan sehari-hari atau bahkan manjadi tema-tema pada khotbah di Gereja, namun dalam pergerakannya istilah transformasi menjadi bahasa yang bias dalam pengertian dan perilakunya. Orang Kristen sebagai wakil Allah di dunia, memiliki panggilan dan tanggungjawabnya kepada Allah
\end{abstract}


dan sesamanya. Hal itu menempatkan Gereja dalam suatu konteks tertentu yang meminta suatu kerangka theologis dan praksis. Pada konteks tersebut panggilan dan tanggungjawab Gereja adalah bermaksud untuk menumbuhkan dan memfasilitasi kasih Allah kepada manusia dan sebaliknya serta kepada sesamanya manusia.

Berkaitan dengan masalah yang telah dipaparkan di atas mendorong penulis untuk meneliti tentang Transformasi Kristen dalam bentuk tulisan, sebagai upaya memberi kontribusi pemikiran kritis dan dorongan praktis terhadap respons dan perilaku yang kurang tepat dalam memberi arti terhadap istilah Transformasi. Tentu materi yang akan dibahas tidak dapat disebut sebagai upaya penjelasan paling sah dan lengkap mengenai transformasi. Namun demikian, tulisan ini paling tidak merupakan suatu upaya alternatif meninjau ulang Gerakan Transformasi serta menawarkan pendekatan yang utuh dalam memaknai transformasi Kristen. Sangat mungkin bahwa penelitian tentang transformasi telah pernah dikemukakan sebelumnya secara lebih rinci. ${ }^{1}$

Menyadari luasnya cakupan tentang permasalahan dan pembahasan mengenai materi Gereja dan Transformasi, maka penulis membatasi pemaparan hanya pada beberapa bagian isu-isu yang berkembang secara umum dan perspektif Perjanjian Lama (PL) dan Perjanjian Baru (PB). Berkaitan dengan hal yang telah dikemukakan sebelumnya, maka penulis berusaha menyajikan materi ini sebagai upaya untuk menyajikan pemikiran transformasi Kristen yang alkitabiah serta menempatkan transformasi pada maksud keutuhan peran Gereja/orang Kristen di dalam dunia. Tulisan ini juga bertujuan dalam kerangka pengembangan teologi sistematika penulis serta pengembangan khazanah pemikiran misi Kristen pada umumnya.

\section{ISU-ISU DAN PERKEMBANGAN GERAKAN TRANSFORMASI (TRANSFORMATION MOVEMENT)}

Dalam rangka upaya untuk memahami dan mendalami gerakan transformasi yang berkembang di Indonesia, sejatinya perlu menelusuri awal kemunculan dan perkembangannya, sehingga menjadi sebuah gerakan yang mempengaruhi banyak Gereja-gereja di dunia umumnya dan di Indonesia khususnya. Pada bagian ini, penulis memaparkan hanya beberapa

\footnotetext{
${ }^{1}$ Lih. beberapa ulasan mengenai transformasi dari beberapa tokoh Gereja dalam karya bersama dengan tema Transformasi Indonesia: Pemikiran dan Proses Perubahan yang Dikaitkan dengan Kesatuan Tubuh Kristus (Jakarta: Metanoia, 2003).
} 
hal yang menjadi perhatian utama dalam mencermati gerakan transformasi tersebut.

\section{Sejarah Gerakan Transformasi}

Pada tahun 1960-an sejalan dengan kebangunan New Age terjadi kebangunan gerakan Kharismatik. Dasawarasa 1970-an ditandai dengan pertumbuhan gerakan itu yang menembus ke lima benua dan memasuki aliran-aliran Gereja, ini disusul dasawarsa 1980-an dimana gerakan ini mulai mencari bentuk dan terjadi disorientasi dimana dari dalamnya lahir banyak aliran-aliran yang menekankan ajaran tertentu dan bahkan sering bersifat sensasional. Salah satu gerakan yang berkembang dan menjadi isu penting adalah pujian dan penyembahan yang disusul dengan Ajaran Kemakmuran (Jonggi Cho) yang merupakan evolusi dari Words of Faith (Kenneth Hagin) yang sarat dengan konsep dan menekankan positive thinking, visualisasi, dan kekuatan kata-kata doa (doa dimensi ke-empat), dan bangunnya ajaran Signs \& Wonders (John Wimber). Kemudian pada tahun 1988 sebagai kelanjutan pergerakan sebelumnya, kemudian muncul sensasi tentang Akhir Zaman yang ramalannya di ulang-ulang di tahun 1992, 1994, 1998 dan 2000. Pada Dasawarsa 1990 gerakan tersebut masih menekankan ajaran kemakmuran dan pertumbuhan Gereja, dan kemudian diselingi sensasi Toronto Blessing (1994-1996). Dari tokoh-tokoh yang umumnya mendukung gerakan kemakmuran, akhir zaman, tanda \& mujizat, dan Toronto Blessing, kemudian diujung milenium ketiga, lahir gerakan Doa Transformasi yang melanda seluruh dunia. ${ }^{2}$

Tokoh utama dibalik gerakan Doa Transformasi adalah Peter Wagner dan George Otis Jr. Wagner adalah orang kedua setelah Donald McGravan yang mengembangkan School of World Mission di Fuller Theological Seminary dan gerakan pertumbuhan Gereja, serta John Wimber, pendiri dari Association of Vineyard Churches and Vineyard Ministries International yang dikenal luas dengan ajaran Signs \& Wonders. ${ }^{3}$ Wagner kemudian merintis gerakan Reformasi Kerasulan Baru ${ }^{4}$

\footnotetext{
${ }^{2}$ Ulasan tentang gerakan words of faith dan signs and wonders dapat dilihat dalam Doa Transformasi Kota, www.yabina.org, diakses tgl 13 Januari 2011.

${ }^{3}$ C. Peter Wagner adalah salah seorang pendiri the World Prayer Center (Pusat Doa Sedunia) di Colorado Springs dan Koordinator dari the United Prayer Track of the A.D. 2000 and Beyond Movement (Jalur Doa Terpadu dari Gerakan Tahun 2000 dan sesudahnya. Gerakan ini di Indonesia dikenal dengan istilah Jaringan Doa Nasional. Mentornya adalah Donald A. McGavran Profesor Pertumbuhan Gereja di Fuller
} 
(New Apostolic Reformation) melalui simposium nasional tentang Gereja pasca-denominasi pada tanggal 21-23 Mei 1996 dimana ia dan beberapa tokoh lainnya mengklaim diri sebagai rasul-rasul khusus pada akhir zaman ini untuk penyatuan umat Kristen di luar tembok denominasi ... Mereka juga enyatakan bahwa telah muncul Gerakan Apostolik yang akan merevolusi Gereja abad ke-21. Gereja generasi akhir akan mengalami Reformasi Apostolik yang akan sama hebatnya dengan generasi awal Gerakan Apostolik. ${ }^{5}$ Dari kubu kedua tokoh tersebut lahirlah konsep pengajaran mengenai peperangan spiritual (spiritual warfare), pemetaan spiritual (spiritual mapping), dan roh-roh teritorial (teritorial spirits) yang pada intinya menekankan peran pendoa syafaat (intercessor) yang memilik kuasa dalam mengubah negara bila dilakukan bersama dengan ajaran mengenai peperangan dan pemetaan spiritual. Dalam film itu diceritakan mengenai empat kota (Cali, Almolonga, Kiambu, dan Hemet) di mana diklaim bahwa metoda baru doa itu telah berhasil mengubah kota-kota itu menjadi kota yang diberkati Tuhan. ${ }^{6}$ Gerakan Doa Transformasi dipublikasikan secara besar-besaran dengan menghadirkan kesaksian yang sarat dengan klaim-klaim subjektif dan spektakuler tanpa memperhatikan keseluruhan peristiwa yang terjadi. Di samping sarat dengan subjektifitas yang tendensius, ajaran Doa Transformasi Kota juga mengusung dan mempopulerkan "kuasa doa dan puasa serta pendoa syafaat" yang

Theological Seminary dan John Wimber pendiri dari Association of Vineyard Churches and Vineyard Ministries International.

4 Towns mengemukakan bahwa wagner pernah menyebut gerakan baru ini (Willow Creek Associates, Calvary Chapels, Vineyard Fellowships) "Gereja-gereja pascadenoinasi," namun istilah ini ditolak karena beberapa orang menganggap istilah itu mengaitkan mereka dengan kegagalan-kegagalan mereka di masa silam, aatau bahkan lebih buruk, istilah itu memberi implikasi ketidakefektifan beberapa denominsi Injili, padahal sebenarnya mereka iti efektif. Karena itulh wagner mengubah judul buku ini menjadi "Reformasi Rasuli Baru"; C. Peter Wagner (ed.), Gereja-Gereja Rasuli yang Baru. Terj. (Jakarta: YPI 'Immanuel', 2001), 7-10; Lih. jg karya C. Peter Wagner, Gempa Gereja. Terj. (Jakarta: Nafiri Gabriel, 1999), 5; Wagner meyebut perubahan terbesar dalam Gereja sejak Reformasi Gereja Protestan sedang berlangsugng saat ini. Ia menamakan fenomena ini sebagai "Reformasi Apostolik Baru." Reformasi Apostolik Baru adalah pekerjaan Tuhan yang luar biasa di abad ke dua puluh yang mengubah Kristen Protestan di seluruh dunia ... Sebenarnya, dari setiap bagian dunia ini, Gereja-gereja apostolic baru telah menciptakan segmen pertumbuhan kekristenan yang paling cepat.

${ }^{5}$ Bill Hamon, Apostolic \& Prophetic Reformation 1. Terj. (Jakarta: Metanoia, 2002), 13; Melalui symposium tersebut kelompok ini menyakini bahwa telah muncul Gerakan Apostolik yang akan merevolusi Gereja abad 21. Nabi-nabi dan rasul-rasul Gereja generasi awal meletakkan fondasi Gereja. Kini, Reformasi Apostolik zaman akhir akan memberikan sentuhan akhir pada Gereja.

${ }^{6}$ Doa Transformasi Kota, www.yabina.org, diakses tgl 13 Januari 2012. 
memberikan hasil yang spektakuler. Sebagai sebuah mobilisasi massa, gerakan transformasi tersebut berhasil menarik banyak minat para hamba Tuhan dan anggota Gereja.

\section{Perkembangan Gerakan Transformasi Dalam Konteks Indonesia}

Pada tahun 1980-an Gerakan Words of Faith yang dikenal dengan prosperity gospel dirintis Kenneth Hagin melanda banyak Gereja, kemudian dikembangkan oleh Benny Hinn, kemudian disusul ajaran Signs \& Wonder dipimpin John Wimbers yang menekankan tanda dan mujizat, ketiga arus gerakan yang biasa dipopulerkan melalui KKR itu memberi dasar timbulnya gerakan yang lebih sensasional lagi pada medio 1990-an yaitu Toronto Blessing. Sekalipun gerakan terakhir ini dirintis salah satu Gereja Vineyard dari lingkungan Signs \& Wonders, John Wimber dan mayoritas dari 600 Gereja Vineyard menolak kehadiran Toronto Blessing yang terkenal dengan label tertawa, mabuk dan berjatuhan dalam roh itu sehingga Gereja Vineyard di Toronto yang dipimpin John Arnott kemudian dikeluarkan dari persekutuan Vineyard. Gelombang Toronto Blessing melanda seluruh dunia termasuk dipopulerkan di Indonesia oleh Gerejagereja yang sudah lebih dahulu terpengaruh Words of Faith dan Signs \& Wonders. ${ }^{7}$ Dari Gereja-gereja yang biasa mempopulerkan Words of Faith, Signs \& Wonders, dan Toronto Blessings, kemudian juga dipopulerkan sensasi Akhir Zaman dan Pengangkatan Jemaat pada tahun 1988, 1992 kemudian 1998, dan lebih-lebih pada tahun terakhir ini dipopulerkan sensasi Pembangunan Bait Allah ke-III dan Lembu Merah. Dramatisasi sensasi Akhir Zaman memuncak pada tahun Y2K alias tahun 2000. Morris Cerullo sendiri mengatakan tak mau membuat rencana pada tahun $2000{ }^{8}$

Di Indonesia, gerakan tersebut dapat diamat-amati pada jaringan pelayanan doa di kalangan Gereja-gereja (walaupun tidak mengikuti keseluruhan arus fenomena yang terjadi pada Gelombang Toronto Blessing) atau yang lebih dikenal dengan Jaringan Doa Nasional (JDN), sebagai motor penggerak berkumpulnya Gereja-gereja dalam kegiatan doa, juga ikut dimotori oleh tokoh-tokoh yang biasa mempopulerkan gerakangerakan Words of Faith, Signs \& Wonders, Toronto Blessings, bahkan Akhir Zaman itu, pada awal milenium ke-III itu ikut menyebarkan gerakan Doa Transformasi sebagai penerus tangan Gerakan Transformasi yang dirintis New Prophet \& Apostle antara lain oleh: Peter Wagner, George

\footnotetext{
${ }^{7}$ Herlianto, Doa Transformasi, www.sabda.org, diakses tgl 19 Januari 2012.

${ }^{8}$ Ibid.
} 
Ottis, dan Cindy Jacobs. Dalam rangka Jaringan Doa Nasional sendiri menjadi National Prayer Comittee (NPC) pada tahun 2003 di Indonesia salah satu pembicara yaitu Hammond mengemukakan bahwa, "pada masa 1997, suatu masa kairos baru di Indonesia telah mulai dan sekarang sedang berjalan dan sedang menuju suatu klimaks dan ledakan besar bagi seluruh bangsa Indonesia." Bila gerakan-gerakan sebelumnya hanya berurusan dengan kebangunan rohani, gerakan Doa Transformasi dipengaruhi semangat transformation, mempopulerkan pembaharuan masyarakat dan negara-negara melalui penekanan Doa dengan para pendoa syafaat (intercessor) menuju pembaharuan dan kesatuan, dan dipercaya bahwa dibawah kepemimpinan tokoh-tokoh New Apostolic di atas yang memuncak pada tahun 2003, dipersiapkan trasformasi masyarakat yang penuh kemuliaan dan kemakmuran. Jargon yang diusung oleh Doa Transformasi adalah, antara lain: doa berjalan (prayer walk), menara doa (prayer tower), konser \& sekolah doa, pemetaan spiritual (spiritual mapping), roh teritorial (teritorial spirit), peperangan rohani (spiritual warfare), memberkati kotakota, dan kemajuan dan kemakmuran negara. ${ }^{10}$

Film-film Transformations yang memberi penekanan kepada peperangan rohani dengan pendoa syafaatnya disebarkan secara luar biasa disertai dengan nubuatan-nubuatan yang menghipnotis mengenai kemajuan dan kemakmuran negara-negara berkat doa-doa mereka. Orang-orang Kristen di JDN percaya bahwa doa bersama umat Tuhan akan mendatangkan kuasa besar bagi terjadinya transformasi di Indonesia bahkan dalam KKR di Denpasar, Royandi Hutasoit yang merupakan salah satu tokohnya mengemukakan bahwa pada tahun 2005, 50\% penduduk Indonesia akan menjadi Kristen. Cindy Jacobs malah menubuatkan Indonesia akan bertobat dan ikan-ikan dari perairan dunia akan mengalir ke perairan Indonesia dan Indonesia akan diberkati dengan berkelimpahan. Ruyandi Hutasoit salah satu tokoh gerakan Doa Trasformasi tidak tanggung-tanggung pada tahun 2001 mendirikan Partai Damai Sejahtera dan berambisi menjadi Presiden RI. Gerakan yang mengandalkan penglihatan dan nubuatan, dan bahwa mujizat Allah bisa dihasilkan melalui doa dan peran pendoa-syafaat itu meyakini bahwa Indonesia juga bisa

\footnotetext{
${ }^{9}$ Jeff Hammond, "Transformasi-Kairos Bagi Indonesia," Di dalam Transformasi Indonesia: Pemikiran dan Proses Perubahan yang dikaitkan dengan Kesatuan Tubuh Kristus (Jakarta: Metanoia, 2003), 27

${ }^{10}$ Lih. ulasan yang lebih luas dalam karya C. Peter Wagner, Doa Peperangan: Strategi untuk Bertempur Melawan Penguasa Kegelapan. Terj. (Jakarta: Metanoia, 1994), dan karya Jonathan David, Jemaat yang Mengalami Strategi-strategi Apostolik. Terj. (Jakarta: Nafiri Gabriel, 2001)
} 
dibangun menjadi maju dan makmur melalui gerakan ini. Partai baru itu memanfaatkan Jaringan Doa Nasional yang ada sebagai jaringan membangun partainya sehingga lolos verifikasi di 21 propinsi. ${ }^{11}$ Sedangkan Njotorahardjo meyakini bahwa gerakan transformasi suatu bangsa dapat terjadi oleh dua kunci utama yaitu, kesatuan para pemimpin (unity among the leaders) dan doa kesatuan (united prayer). ${ }^{12}$ Ia tidak mengemukakan sama sekali upaya yang harus dilakukan oleh para pemimpin Gereja dalam menyejahterakan masyarakat dan bangsa.

\section{Doktrin Gerakan Transformasi}

Slogan yang diusung Gerakan Transformasi sarat dengan pemikiran bahwa dunia ini akan berakhir, sehingga perlu memobilisasi potensi Gereja untuk mengkristenkan atau mengubahkan seluruh dunia melalui doa dan peperangan rohani. Usaha tersebut meliputi Negara-negara dan kota-kota serta daerah-daerah, sehingga makin menjamurnya gerakan-gerakan Doa yang dinamakan Menara Doa dan Doa Sekota.

Ajaran Signs \& Wonder (Wimber) yang lebih mengutamakan dan bahkan menempatkan mujizat dan tanda-tanda sebagai dasar dalam kekristenan, dengan menggunakan nama Yesus. Mereka meyakini atas nama iman bahwa keselamatan dalam penebusan Kristus belum lengkap dan harus diisi dengan bukti tanda dan mujizat, demikian juga Otis menyebut bahwa peran Tuhan Yesus di kayu salib tidak berarti kecuali manusia melalui para rasul barunya mampu memetakan dunia spiritual dan memerangi roh-roh teritorial dengan kuasa doa syafaat dan puasa manusiawi. Meyakini bahwa Iblis menguasai daerah-daerah tertentu sehingga perlu mengadakan peperangan untuk mengalahkan penguasapenguasa atau roh-roh teritorial. Dengan dilatarbelakangi pemahaman yang demikian maka muncullah konsep mengenai "doa peperangan."

Konsep mengenai Doa Berjalan atau Doa Keliling (prayer-walk) dengan menara doanya untuk menguduskan suatu kawasan, maupun doa memberkati suku-suku atau kawasan tertentu. Jelas menekankan ajaran Word Faith yang menjadikan doa sebagai suatu kekuatan spiritual seperti mantra dan bukan sebagai alat dialog dengan Tuhan dan Tuhan-lah yang mendengar yang akan memberikan jawaban-Nya. ${ }^{13}$ Wagner menggunakan

${ }^{11}$ Herlianto, Doa Transformasi, www.sabda.org, diakses tgl 19 Januari 2012

${ }^{12}$ Niko Njotorahardjo, "Kesatuan Tubuh Kristus Menuju Transformasi Bangsa," DalamTransformasi Indonesia (Jakarta: Metanoia, 2003), 3

${ }^{13}$ Doa Transformasi Kota, www.yabina.org, diakses tgl 13 Januari 2012 
narasi tentang Yesus berada di padang gurun sebagai dasar dalam melakukan doa peperangan. Ia memaparkan, bahwa setelah Yesus penuh dengan Roh Kudus pada saat pembaptisan, Roh Kudus adalah sumber kuasa Yesus, demikian pula para pengikut-Nya. Mengutip dari Yohanes 16:14, Wagner menjamin bahwa orang-orang percaya akan melakukan perkara-perkara yang lebih besar daripada yang Yesus sendiri lakukan. Kemudian ia lebih lanjut memaparkan peristiwa-peristiwa di mana Yesus menyerang Iblis dan sekaligus pengajaran Yesus tentang perlunya penyerangan, yang kemudian diakhiri dengan contoh-contoh alkitabiah tentang penyerangan rohani. Semuanya ini dimaksudkan untuk mengatakan: Yesus menyerang, demikian pula kita! ${ }^{14}$

\section{Transformasi Merupakan Dimensi Pertumbuhan Kuantitas}

Isu Gereja yang lebih menekankan pertumbuhan Gereja atau dimensi kualitatif sebagai doktrin Gereja begitu mengemuka dalam Gerakan Transformasi, dan bahkan bisa jadi merupakan isu sentral bagi banyak Gereja di Indonesia. Di Indonesia, pengertian peran Gereja yang identik dengan penginjilan dan pertumbuhan Gereja telah ditanamkan dengan begitu kuat. Penekanan arti yang kuantitatif Gereja diprakarsai, diidentifikasi serta dipertajam oleh George W. Peters, dengan merumuskan pengertian peran Gereja dalam hal misi dengan membedakan antara mission dan missions. Ia mengemukakan sebagai berikut:

Misi dalam pengertian saya, merujuk pada penugasan Gereja Yesus Kristus yang bersifat biblikal sepenuhnya. Penugasan tersebut adalah dalam suatu pengertian yang bersifat menyeluruh, termasuk pelayanan-pelayanan Gereja yang ke atas, ke dalam dan ke luar. Itulah Gereja yang diutus ke dalam dunia .... Misi adalah suatu istilah yang khusus. Saya maksudkan adalah pengutusan pribadipribadi yang berwibawa melampaui batasan-batasan Gereja PB dan pengaruh Injil yang dibawanya untuk memberitakan Injil Yesus Kristus di wilayah-wilayah yang sangat miskin dan papa, untuk memenangkan petobat-petobat dari iman mereka yang lain, tanpa iman, dan beriman kepada Yesus Kristus, dan memberdayakan, melipatgandakan Gereja-gereja lokal yang akan menghasilkan buah kekristenan dalam masyarakat dan negara tersebut. ${ }^{15}$

\footnotetext{
${ }^{14}$ Wagner, Doa Peperangan ..., 53-75

15 George W. Peter, A Biblicak Theology of Mission (Chicago: Moody Press, 1974), 11
} 
Paradigma Peters tersebut diakui menjadi acuan bagi pengertian misi dalam hubungannya dengan penginjilan dan pertumbuhan Gereja seperti yang dikemukakan oleh Yakob Toatmala. ${ }^{16}$

Isu pertumbuhan Gereja, lima belas tahun terakhir ini berkembang pesat di Asia serta khususnya Indonesia. Hadirnya Gerakan Transformasi amat memengaruhi paradigma para pendeta dan para majelis Gereja-gereja, serta para aktivis Gereja di Indonesia, sehingga memiliki spirit yang kuat untuk mengembangkan Gereja secara kuantitas. Hal itu mendapat dukungan dari propaganda Gereja yang mengklaim sebagai Gereja terbesar di dunia yang berada di Korea, ditambah dengan publikasi tulisan George W. Peter dan Donal McGavran. ${ }^{17}$ Pemahaman Gerakan Transformasi juga dipengaruhi oleh School of World Mission and Institute of Church Growth dengan tokoh utamanya Donald McGavran. Pertumbuhan Gereja tidak hanya menjadi tujuan misi, tetapi lebih dari itu, usaha misi harus dijalankan dengan prinsip-prinsip pertumbuhan Gereja. ${ }^{18}$ Seminar-seminar pertumbuhan Gereja yang diprakarsai dan didanai oleh Gerakan Transformasi menjadi trend di banyak kota besar di Indonesia. Maka lahirlah Gereja-gereja lokal yang memiliki ribuan anggota dengan ditandai gedung Gereja yang besar, mewah dan eksklusif. Wagner mengemukakan bahwa selama 30 tahun ia menyandang gelar "professor pertumbuhan Gereja," ia menyadari bahwa Gereja apostolik baru merupakan kelompok Gereja yang pertumbuhnnya paling cepat di enam benua di dunia. ${ }^{19}$

Pengaruh para tokoh Gereja tersebut amat kuat mempengaruhi doktrin bagi gerakan misi, sehingga tendensi misi masa kini masih terlihat hanya menekankan pada satu sisi, yakni penginjilan dan pertumbuhan Gereja. Misi Gereja kemudian menjadi semacam kompetensi penuh kecemburuan antardenominasi Gereja yang melancarkan foreign mission dari Barat. Peran Gereja seperti ini akhirnya menjadi ecclesia gloriae yang melahirkan dan menumbuhkan Gereja-gereja introvert di Asia. ${ }^{20}$ Berkaitan dengan hal itu, David Fisher has pointed this out in blunt terms:

16 Yakob Tomatala, Teologi Misi: Pengantar Misiologi: Suatu Dogmatika Alkitabiah Tentang Misi, Penginjilan dan Pertumbuhan Gereja (Jakarta: Institut Filsafat Theologi dan Kepemimpinan Jaffray, 2003), 20

${ }^{17}$ Publikasi buku oleh George W. Peter, A Biblical Theology of Mission, Chicago: Moody Press, 1974; Donald A. McGavran, Contemporary Theologies of Mission (Grand Rapid, Michigan: Baker Book House, 1983).

18 J. Verkuyl, Contemporary Missiology: An Introduction (Grand Rapids, Michigan: Eerdmans, 1978), 184, 190

${ }^{19}$ C. Peter Wagner, Gempa Gereja. Terj. (Jakarta: Nafiri Gabriel, 2000), 7-8

${ }^{20}$ C. S. Song, Christian Mission in Reconstruction: An Asia Analysis (New York: Orbis Book, 1977), 13 
"Theological reflection or, more particularly, integrative theological thinking about the church, especially the local church, is missing. Ecclesiology has been marginalized and detheologized. "21

Dengan demikian, pergeseran paradigma dan kultur Gereja dalam memahami Gereja dan Transformasi adalah lebih merupakan perumusan bahwa doktrin persepsi dikotomi. Deskripsi yang salah dalam memahami dan merumuskan doktrin Gereja dan Transformasi akan cenderung dapat mengakibatkan perilaku yang tidak tepat pula. Kesalahannya bukan terletak pada doktrin, tetapi pada cara pemahaman dan perumusan doktrin secara salah, serta terhadap natur dan tujuan doktrin. Gerakan transformasi yang berkembang di Indonesia dapat diidentikkan dengan gerakan Reformasi Apostolik Baru yang mengklaim sebagai perwujudan dari akhir masa karya Allah di dalam dunia yang akan memasuki masa akhir zaman, serta menekankan kuantitas.

\section{PERSPEKTIF BIBLIKA TENTANG TRANSFORMASI}

PL dan PB, tidak hanya berisi narasi sejarah dan aspek moralitas belaka, tetapi juga sarat dengan nilai-nilai spiritual, pembaruan sosial, politik, dan ekonomi serta keagamaan. Berkaitan dengan hal itu, maka pada bagian ini penulis membahas beberapa bagian mengenai dasar-dasar transformasi sebagai wacana dan pergerakan perubahan dalam Gereja yang diharapkan dapat menjadi pijakan dalam meneliti dan mengembangkan tindakan-tindakan yang positif serta konstruktif bagi upaya Gereja dalam hal transformasi. Penelitian beranjak dari sumber Alkitab mengenai transformasi secara terbatas. Artinya tidak secara keseluruhan bagian Alkitab, melainkan beberapa bagian saja yang dikemukakan, termasuk di dalamnya fungsi mempertahankan dan mengoreksi pergerakan perubahan.

\section{Perjanjian Lama}

Allah adalah pencetus dan pemrakarsa serta dinamisator transformasi yang sesungguhnya. Allah adalah awal dan yang sudah memulai (originator) transformasi sesungguhnya pada waktu ia 1996), 76

${ }^{21}$ David Fisher, The $21^{\text {st }}$ Century Pastor (Grand Rapids, Michigan: Zondervan, 
mengadakan penciptaan dan ketika manusia jatuh dalam dosa (Kej 1-3). Ia menciptakan semuanya menjadi "sungguh amat baik" (Kej 1-2). Ia memiliki otoritas mutlak sebagai pencipta dunia dan yang mengadakan transformasi. Otoritas Allah sebagai pencipta tidak hanya berbicara mengenai teori penciptaan tetapi juga mengungkapkan tindakan Allah yang agung terhadap alam semesta yang kompleks namun tertata dengan rapi seperti yang diungkapkan oleh Karman, yaitu: "teologi penciptaan adalah kepercayaan tentang Allah sebagai Pencipta alam semesta yang kompleks namun tertata rapi, termasuk juga sebagai penjaga kelangsungan dunia ciptaan sampai sekarang, menopang segala yang ada dengan firman-Nya yang penuh kekuasaan (Ibr 1:3)." ${ }^{22}$ Berkaitan dengan hal itu, Smith memaparkan bahwa Allah terus-menerus terlibat didalam kelangsungan dan pergerakan alam semesta, yang di dalamnya termasuk manusia. Di dalam kedaulatan Allah nyata karya-Nya yang adalah Tuhan atas segala ciptaan, bukan hanya sebagian. Kerajaan-Nya meliputi seluruh kehidupan. Allah menciptakan dunia sebagai suatu kesatuan; dunia jatuh ke dalam dosa secara total, dan akhirnya dunia akan diperbarui secara menyeluruh. ${ }^{23}$

Ketika manusia jatuh dalam dosa, Allah tidak hanya berdiam diri tetapi Ia mencari dan berinisiatif untuk mengembalikan manusia pada relasi dan tempat yang sepantasnya di hadapan Allah, agar manusia menjadi manusia yang sesungguhnya sesuai dengan maksud kehendak-Nya, Allah dalam kedaulatan dan kehendak-Nya sendiri berinisiatif mencari manusia, bukan manusia yang mencari Allah (Kej 3). Kejadian pasal tiga menyatakan kebutuhan manusia akan pertolongan, tetapi sekaligus menyatakan tindakan Allah yang agung di dalam kehendak-Nya, rencanaNya dan kedaulatan-Nya serta kasih-Nya dalam melakukan transformasi. Allah memanggil manusia dan berfirman kepadanya: "Dimanakah engkau?" Ini merupakan seruan transformasi, Allah yang memanggil manusia dari ketakutan dan ketersembunyiannya untuk kembali memiliki hubungan yang benar dan harmonis dengan Allah seperti sebelumnya. Kidner menjelaskan, bahwa hanya suara Allah yang menerobos ketersembunyian manusia, God's first word to fallen man has all the marks of grace. It is a question, since to help him He must draw rather than drive him out of hiding. Only a voice penetrates his concealment. ${ }^{24}$ Kejatuhan

${ }^{22}$ Yonky Karman, Bunga Rampai Teologi Perjanjian Lama (Jakarta: BPK Gunung Mulia, 2004), 18-19

${ }^{23}$ Gary Scott Smith, "Reformasi: Luther, Calvin, dan Kaum Anabaptis," Dalam Membangun Wawasan Dunia Kristen. Vol 2. Terj. (Surabaya: Momentum, 2008), 260

${ }^{24}$ Derek Kidner, "Genesis," in Tyndale Old Testament Commentaries (Leicester: Inter-Varsity Press, 1967), 70 
manusia dalam dosa menyatakan betapa dalamnya kerusakan yang terjadi sehingga manusia membutuhkan pertolongan yang berasal dari luar dirinya sendiri. Berkaitan dengan hal itu, Sire memberi komentar bahwa manusia membutuhkan penataan ulang antara manusia dengan Allah, dengan mengatakan: "Dan demikian juga kita sebagai umat manusia! Alur pergerakan dunia terbuka bagi penataan ulang oleh kedua pihak (Allah maupun manusia). Maka kita menemukannya ditata ulang secara drastis di dalam kejatuhan. Adam dan Hawa membuat suatu pilihan yang memiliki signifikansi yang luar biasa besar. Tetapi Allah membuat satu pilihan lain yang di dalam menebus umat melalui Kristus." ${ }^{25}$ Manusia tidak mampu menata ulang atau mereformasi dirinya sendiri, hanya oleh anugerah Allah yang nyata melalui inisiatif dan tindakan Allah, transformasi yang sesungguhnya dapat terjadi. Urgensitas transformasi ditandai dengan keadaan manusia yang berada dalam ketakutan dan keterasingan serta kebutuhan manusia untuk penataan ulang (Kej 3:9-10). Dalam konteks tersebut seruan Allah bukanlah sekedar seruan belaka, tetapi merupakan domain pergerakan transformasi dan secara signifikan merupakan seruan suara transformasi sejati, sarat dengan nilai-nilai pembaruan bagi manusia.

Amos merupakan figur penggerak dan penyuara transformasi yang menolak disebut sebagai nabi, karena memiliki latarbelakang seorang awam dari tengah-tengah rakyat biasa, "peternak domba" dan "pemungut buah ara hutan" (Am 1:1; 7:14). Namun, ia diutus Allah untuk menyuarakan gerakan transformsi di Kerajaan Utara. Berkaitan dengan hal itu, Andrew Hill memberi komentar bahwa: "kemurtadan rohani, keruntuhan baik bidang moral dan sosial, serta kemerosotan politik Kerajaan Utara menyebabkan Allah mengutus Amos dari Yehuda untuk menyeberangi perbatasan dan bernubuat di Betel di kawasan Israel."26 Inilah yang menjadi latarbelakang dan sekaligus sebagai motivasi Amos dalam pergerakan pembaruan. Dengan pemberitaannya yang jelas dan tegas, khususnya dengan penolakannya terhadap sistem masyarakat yang menindas orang-orang lemah/kecil dengan memakai alasan-alasan rohani. Pada pasal 2, 3-6, Amos menyampaikan kecaman terhadap umat Allah yang dikasihi-Nya, mereka justru akan mengalami hukuman yang lebih berat. "Oleh karena mereka menjual orang benar karena uang ... mereka menginjak-injak kepala orang lemah dan membelokkan jalan orang sengsara serta mereka merebahkan diri... di atas pakaian gadaian orang"

25 James W. Sire. The Universe Next Door: A Basic Worldview Catalog. Terj. (Surabaya: Momentum, 2005), 19

${ }^{26}$ Andrew E. Hill \& John H. Walton, Survei Perjanjian Lama. Terj. (Malang: Gandum Mas, 1996), 613 
(Am 2:6-8). Berkaitan dengan hal itu, Andrew Hill mengemukkan bahwa berita yang disampaikan Amos meliputi seruan pertobatan dan perubahan perilaku. Ia memaparkan sebagai berikut:

Amos menyalahkan secara khusus perbuatan-perbuatan ketidakadilan sosial dan kemunafikan rohani. Beberapa tujuan pesan ini meliputi seruan yang ditujukan pada beberapa orang untuk bertobat dari dosa pribadi, dorongan untuk kembali pada normanorma perilaku yang sesuai dengan persyaratan-persyaratan perjanjian Yahweh, dan penolakan gagasan yang meluas bahwa "hari Tuhan" hanya merupakan hari berkat secara nasional. ${ }^{27}$

Gagasan tersebut menjadi berita yang mendominasi pemberitaan Amos agar bangsanya kembali kepada nilai-nilai dan perilaku yang sesuai dengan kebenaran firman Allah.

Yesaya dikenal sebagai penasihat raja yang aktif melakukan gerakan pambaruan bagi bangsanya dengan menyuarakan perubahan. Pada pasal 1-5, Yesaya menyampaikan dan menegaskan kesalahan bangsanya serta menyatakan kebutuhan akan pembaruan dengan mengatakan "Belajarlah berbuat baik; usahakanlah keadilan, kendalikan orang kejam; belalah hak anak-anak yatim, perjuangkan perkara janda-janda (Yes 1:17). Di tengah-tengah bangsa dan pemimpin yang memutar balikkan hukum, korupsi, menindas orang-orang yang lemah secara sosial dan ekonomi (Yes 1:21-23). Yesaya tampil dalam gelora dan semangat yang tak digentarkan oleh ancaman dari berbagai pihak. Berkaitan dengan hal itu, Christoph Barth memberi ulasan tajam mengenai gaya bahasa Yesaya dalam menyuarakan transformasi, bahwa: "Yesaya terkenal dari gaya bahasanya yang lancar, indah dan berbobot. Dia pandai menarik perhatian orang, lalu dengan tiba-tiba melabrak dengan hebatnya, meskipun sebaliknya pula pandai menghardik dan mengancam, lalu dengan tidak disangka-sangka membayangkan pengharapan baru." 28 Yesaya menyampaikan suara transformasi dengan gaya bahasa menarik, ia menyuarakan pertobatan bagi bangsanya untuk kembali pada tatanan Hukum Allah. Inilah tugas dari seorang yang diutus oleh Allah, menyampaikan kedaulatan Allah yang dapat mendatangkan pembaruan dan kelepasan. Andrew Hill memberi konklusi dengan jelas pada arah berita pembaruan Yesaya, dengan mengemukakan bahwa: "Tujuan seorang nabi adalah menyampaikan perkataan yang diberikan Allah kepadanya untuk disampaikan. Sebagian

\footnotetext{
${ }^{27}$ Ibid., 613-614

${ }^{28}$ C. Barth, Theologia Perjanjian Lama. Terj. (Jakarta: BPK Gunung Mulia, 1989), 56
} 
besar ucapan-ucapan ilahi dibagian pertama kitab Yesaya (1-39) berisi tuduhan dan hukuman. Pasal 40-66 lebih banyak berhubungan dengan pengampunan dan kelepasan dari Allah serta pemulihan kembali Israel. ${ }^{29}$ Signifikansi berita transformasi Yesaya dapat diamat-amati dalam beberapa hal yang terjadi, yaitu: Pertama, Yesaya mencela dan mengancam umat Tuhan yang sudah memperoleh segala jenis berkat tetapi mereka membalasnya dengan keangkuhan dan pemberontakan. Kedua, Yesaya memberitakan penolakan dan penghukuman tidak dalam arah membinasakan, melainkan hukuman Allah dimaksudkan untuk memperbaiki dan memurnikan (Yes 1:25). Berkaitan dengan hal itu, Chisholm memberi komentar bahwa, "Divine judgment would not bring Israel's history to a screeching, permanent halt. As noted, judgment was merely a necessary step toward the realization of God's ideal for the nation. Even through the smoke of judgment, one could discern a ray hope. " ${ }^{30}$ Allah bertindak dengan tegas adalah justru karena kasih-Nya yang tetap hangat (bnd. 'tanaman kegemaran-Nya,' Yes 5:7) dan senantiasa memberi pengharapan. Ketiga, Dalam perannya menyuarakan transformasi, Yesaya harus menggumuli sesuatu yang lebih dahsyat; nubuat dan nasihatnya bukan hanya diabaikan, melainkan justru "membuat hati bangsanya lebih keras" (Yes 5, 8, 22). Satu-satunya harapan adalah melalui penghukuman dan penderitaan, Namun demikian, Tuhan sendiri yang menyembuhkan umat-Nya. Keempat, pemberitaan Yesaya, dengan tekanan kepada panggilan umat orang-orang percaya untuk pembangunan masyarakat yang adil dan perdamaian, serta undangannya agar umat-Nya tetap percaya di tengah-tengah kemelut bangsa. ${ }^{31}$

Ezra dan Nehemia dapat dilihat sebagai dua nabi yang memiliki latar belakang pelayanan dengan isu-isu yang sama dalam pergerakan mereka sebagai transformator. Dalam arah yang sama Merrill mengemukakan bahwa, secara historis dan religius Ezra dan Nehemia memiliki latar belakang yang sama dalam pelayanan. Ia memberi komentar, "Moreover, as one reads both parts at one sitting he comes to appreciate their common historical and religious setting, their concern with the same issues, and their reflection of identifical point of view." ${ }^{32}$ Ezra maupun

\footnotetext{
${ }^{29}$ Hill \& Walton, Survei Perjanjian Lama ..., 528

${ }^{30}$ Robert B. Chisholm, Jr, "A Theology Of Isaiah," in A Biblical Theology of The Old Testament (Chicago: Moody Press, 1991).

31 Bd. Barth, Theologia Perjanjian..., 58-59; Barth mengulas keempat signifikansi tersebut dengan lebih luas.

${ }^{32}$ Eugene H. Merrill, "A Theology of Ezra-Nehemiah and Esther," in A Biblical Theology of The Old Testament (Chicago: Moody Press, 1991), 189
} 
Nehemia mendapati bahwa umat Allah mengotori diri mereka sendiri dengan mengawini bangsa-bangsa kafir yang pada akhirnya membahayakan kelangsungan Israel sebagai kesatua etnik dan kesatuan rohani. Ezra menghadapi tantangan dalam upaya pembangunan Bait Suci, serta perbaikan tembok Yerusalem pada zaman Nehemia. Dalam pembuangan di Persia, Nehemia mendengar tentang terbongkarnya tembok-tembok Yerusalem dan tentang keadaan yang menyedihkan bangsanya. "Bangunlah aku pada malam hari bersama-sama beberapa orang saja yang menyertai aku. Aku tidak memberitahukan kepada siapapun rencana yang akan kulakukan untuk Yerusalem, yang diberikan Allahku dalam hatiku..." (Neh 2:12). "Mari, kita bangun kembali tembok Yerusalem". Ia menyuarakan pembaharuan semangat dan motivasi kebersamaan ditengah-tengah bangsanya yang mengalami kelesuan dan ketidakberdayaan (Neh 2:17-18). Berkaitan dengan hal itu, Merrill memberi komentar bahwa tindakan Nehemia dan Ezra tidak hanya bersifat struktur pisik melainkan simbol keberlangsungan dari masa lalu dan keyakinan akan masa depan. Ia mengemukakan sebagai berikut:

The final expression of community restoration was the rebuilding of the physical structures of the city and nation. This was necessery not only for practical reasons of housing and community resources but also as a symbol fo continuity with the past and confidence in the future. Immediately on their return, then, the people under Zerubbabel and Jhosua commenced their building projects, in particular the Temple of the Lord (Ezr 3:8-13). Slowly the work progressed under these leaders and others, including Ezra and Nehemiah, until it was finished and stood as a monument to the faithfullness of Yahweh to His people. ${ }^{15}$

Pada pasal 9-10 di bawah pimpinan Ezra, ia melakukan gerakan transformasi rohani dan sosial. Ezra prihatin dengan kondisi bangsanya, karena "bangsa yang kudus" telah tercemar (9:2). Reaksi Ezra sungguh mengejutkan: perasaan sedih dan berduka, berpuasa dan mencabut rambutnya. Kemudian ia berdoa dengan segenap hati mengaku dosa (9:316). Inilah teladan sikap seorang transformator yang sejati. Pembaruan rohani tersebut dideskripsikan dengan tindakan penyingkiran isteri-isteri kafir yang telah dinikahi oleh bangsa Israel, pernikahan yang bertentangan dengan kehendak Allah. Respon yanag dideskripsikan adalah rakyat bertobat dan mohon pengampunan serta merekonstruksi komitmen baru kepada Allah. Pada Nehemia pasal 8-10 menjelaskan secara dramatis

\footnotetext{
${ }^{15}$ Merrill, “A Theology of Ezra-Nehemiah and Esther,” 195
} 
transformasi yang dilakukan oleh Ezra dengan mengembalikan bangsanya kepada Kitab Suci. Ketaatan kepada Kitab Suci merupakan tema penting dalam gerakan transformasi kitab Ezra maupun Nehemia. Berkaitan dengan hal itu Howard Jr memberi komentar, bahwa "banyak perkara dalam kitab Ezra dan Nehemia memberikan kesan adanya satu perhatian besar untuk melakukan segala sesuatu sesuai dengan Taurat Musa. Ketaatan yang sungguh-sungguh kepada Taurat kini merupakan manifestasi yang kelihatan dari kesetiaan bangsa ini." 16 Peristiwa dramatis tersebut dijelaskan dengan kesungguhan rakyat yang terharu sampai menangis, serta diikuti adanya pembaruan komitmen ulang dari bangsa Israel. Inilah gerakan transformasi yang menghasilkan pembaruan yang mengembalikan komitmen bangsa Israel. Dengan menarik Howard Jr memberi komentar mengenai reformasi yang di sajikan kitab Ezra dan Nehemia. Ia mengemukakan bahwa: " Kitabkitab ini dikemas begitu ketat dengan pesan spiritual yang siap digali. Kedua kitab ini menyampaikan kekayaan rohani pada masa-masa selama umat Allah diliputi hal-hal yang tidak menyenangkan." 17 Pada keseluruhan struktur narasi yang telas dijelaskan di atas dapat dikemukakan bahwa di dalam PL, baik Allah dan para nabi dan orang yang diutus Allah melayani bangsa dan negaranya sarat dengan nilai-nilai pergerakan transformasi.

\section{Perjanjian Baru}

Tuhan Yesus dapat disebutkan sebagai pemberita dan sekaligus menjadi inti berita transformasi yang memberi dan sekaligus merupakan teladan seorang transformator yang sesungguhnya. Hal tersebut dapat diamat-amati dari narasi yang dikemukakn oleh keempat Injil. Yesus Kristus yang datang ke dunia merupakan berita perubahan yang jauh lebih radikal dari perubahan-perubahan itu sendiri. Signifikansi perubahan sejarah abad manusia diperlihatkan dengan kehadiran para malaikat yang memperlihatkan wujudnya kepada manusia untuk menyampai berita sukacita besar sebagai suara transformasi (Mat 1-2; Luk 1-2). Berita yang dicatat oleh penulis Matius menyatakan inti berita transformasi sesungguhnya yang memberi perubahan pada sejarah besar manusia, "Ia akan melahirkan anak laki-laki dan engkau akan menamakan Dia Yesus, karena Dialah yang akan menyelamatkan umat-Nya dari dosa mereka" (Mat 1:21). Dia tidak hanya menjadi inti berita transformasi, melainkan sekaligus

${ }^{16}$ David M. Howard Jr, Kitab-Kitab Sejarah dalam Perjanjian Lama. Terj. (Malang, Gandum Mas, 2002), 380

${ }^{17}$ Ibid., 340 
pada diri-Nya melekat berita itu sendiri, dan menjadi pelaku transformasi. Hal ini lebih dari cukup untuk sebuah konsepsi, konfesi dan rekonstruksi transformatoris. Bagi orang-orang pengecut, munafik dan penguasa korup, serta yang tidak berkenan bagi Allah, berita tersebut pada satu sisi adalah api yang menimbulkan kegentaran dan ketakutan tetapi pada sisi lain, sekaligus menjadi api yang menyulut amarah yang besar (Mat 2:1-18).

Kitab Injil memberikan suatu paradigma yang jelas, bahwa cara hidup, cara berpikir dan tindakan-tindakan Yesus adalah bingkai seorang transformator. Ia membersihkan Bait Allah dari konspirasi busuk para penguasa Bait Allah yang mencari keuntungan ekonomi dan monopoli atas nama agama (Mat 21:12-13; Mrk 11:15-19; Luk 19:45-48; Yoh 2:13-16). Suara pembaruan Yesus mengancam status quo yang berkembang dan yang dipertahankan oleh kebanyakan orang pada masa itu, secara khusus para imam. Ia menggoncang kehidupan yang tenang dan nyaman dari golongan Saduki, Romawi, dan Farisi. Berkaitan dengan hal itu, Kraybill menghubungkan tindakan Yesus tersebut sebagai seorang revolusioner tanpa kekerasan, dengan mengemukakan sebagai berikut.

Yesus memang seorang revolusioner, ketika Ia menyerang akar permasalahannya- kejahatan yang sering mengikat niat dan pranatapranata manusia. Ia menyerukan pertobatan. Ia mengimbau untuk mengasihi. Ia mengumumkan bahwa hanya Allah yang harus disembah... Tetapi revolusi sungsang-Nya menggantikan kekuatan dengan penderitaan dan kekerasan dengan kasih yang kuat."18

Yesus menggoncang pranata-pranata sosial dan struktur kemasyarakatan pada masa itu. Ia melayani dan ada bersama-sama dengan orang-orang yang diberi stigma oleh masyarakat umum sebagai orang yang sangat berdosa dan perlu dijatuhi hukuman (pemungut cukai, perempuan Samaria, perempuan yang berzinah). Namun dengan kasih dan kehangatanNya, Ia bergaul dan berani menerima prasangka-prasangka bahkan kebencian dari kelompok/golongan masyarakat tertentu atas sikapnya itu.

Apa yang dilihat Yesus adalah lingkaran kekerasan yang menimpa para petani Galilea. Para petani yang lain tidak hanya miskin, tetapi mereka juga dieksploitasi dan ditindas tidak hanya oleh orang-orang Romawi tetapi juga oleh Herodes dan para tuan tanah yang kaya raya. Mereka menanggung beban pajak yang berat sehingga mereka terus-menerus terbelit utang. Sementara keadaan mereka semakin buruk, apa yang berkembang adalah lingkaran kekerasan. Pada konteks pergulatan sosial

${ }^{18}$ Donald B. Kraybill, Kerajaan yang Sungsang. Terj. (Jakarta: BPK Gunung Mulia, 2005), 45 
politik pada masa-Nya, Yesus merupakan individu yang unik dengan peran yang Ia mainkan dalam sejarah politik. Yesus sadar penuh (Him self understanding) akan hal itu. Yesus tidak memandang orang di depannya hanya sebagai seorang pengemis, atau hanya sekedar sebagai prajurit Romawi, atau hanya sebagai orang Farisi, atau juga hanya sebagai seorang pemuda kaya. Yesus mengasihi mereka tanpa memandang label-label yang melekat pada mereka, tanpa memandang penampilan dan kesalahan mereka. Dalam kerangka reformasi-Nya, mereka adalah orang-orang yang menjadi sasaran kasih dan pertolongan Allah. Bahkan para musuh-Nya mengenali bahwa Yesus sepenuhnya tidak memihak dan bahwa Yesus tidak peduli pada derajat atau status seseorang (Mrk 12:14). ${ }^{19}$ Berkaitan dengan hal itu, maka dapat disebutkan bahwa ide mengenai transformasi telah dimulai dari Allah sendiri; Allah adalah pencetus ide dan sekaligus pelaku transformasi yang sesungguhnya, Allah adalah Allah yang menyuarakan transformasi, dan Allah adalah Allah yang sungguh-sungguh melakukan trnasformasi bagi umat-Nya, dan Allah adalah Allah yang menjadi inti berita transformasi sekaligus memfasilitasi penaataan ulang relasi manusia dengan Allah, serta memanusiakan manusia pada maksud Allah. Hal itu nampak ketika Allah mencari manusia yang berdosa dan memanggil mereka dari ketersembunyiannya dan memfasilitasi manusia untuk menemukan tempatnya di hadapan Allah (Kej 3:1-21), serta yang menyatakan kehadiran dan karya penebusan oleh dan di dalam Kristus. Ide mengenai perubahan-perubahan ada di dalam rencana, kedaulatan dan otoritas Allah. Hanya di dalam dan melalui pengertian akan kedaulatan, otoritas, kehendak dan rencana serta kasih Allah sendiri, manusia menemukan transformasi yang sesungguhnya.

Dengan demikian transformasi yang sesungguhnya tidak dimulai pada inisiatif manusia maupun lembaga-lembaga yang diciptakan oleh manusia itu sendiri, melainkan dimulai dan dinyatakan serta digerakkan oleh Allah Tritunggal. Allah yang telah memulai dan yang akan terusmenerus melakukan transformasi dan transformasi tersebut juga menyebar melalui orang-orang yang dipanggil, digerakkan dan dipakai-Nya, dan hal itu selalu berada pada otoritas-Nya. Jika paradigma di atas kita gunakan sebagai suatu pendekatan transformasi maka dapat dikemukakan bahwa transformasi yang mengemuka secara khusus adalah transformasi yang lebih mengacu pada konteks Gereja. Sebagai orang-orang percaya yang telah mengalami transformasi tersebut, Allah melalui Gereja atau orang

${ }^{19}$ Albert Nolan, Jesus Today. Terj. (Yogyakarta: Kanisius, 2006), 103-110 
percaya memiliki peran sebagai alat-Nya untuk memberitakan dan mewujudnyatakan pengalaman transformasi kepada sesamanya.

\section{KEUTUHAN KONSTRUKSI GEREJA DAN TRANFORMASI}

Sejatinya tidak ada dikotomi dalam hal pemahaman Gereja dengan praksis kehidupan umat Kristen. Panggilan Gereja dalam merumuskan doktrin dengan implementasi bukanlah dua ranah yang berbeda, sebab Gereja atau orang Kristen dengan panggilan perannya sebagai transformator beranjak pada keyakinan terhadap firman Tuhan sebagai acuan berpikir dan berperilaku. Pada bagian ini penulis mengadakan evaluasi serta memberi usulan yang sekiranya dapat menjadi pertimbangan dalam mengembangkan paradigma Gereja dan Transformasi, yaitu:

\section{Evaluasi Terhadap Doktrin Gerakan Transformasi}

Secara teologis adalah sesuatu yang lemah dan tidak memiliki dasar biblika yang kuat (bukan berarti tidak menggunakan Alkitab) untuk memberi dukungan kepada Gerakan Transformasi yang membagi-bagi geografi dunia menjadi teritori yang dihuni kuasa kegelapan dan yang dihuni oleh Roh Tuhan, apalagi kalau hal itu bisa dipetakan oleh manusia secara visual (bandingkan dengan perumpamaan Gandum \& Lalang yang dikemukan oleh Tuhan Yesus). Karena pada dasarnya dunia adalah dunia milik Allah. Hal ini tidak berarti bahwa kita menolak adanya kuasa dan pengaruh roh-roh jahat di dunia, melainkan menolak pembagian wilayah atau dunia seperti yang dikemukakan oleh Gerakan Transformasi.

Nabi Yunus yang tidak mendoakan kota Niniwe, namun Niniwe diberkati karena pertobatan penduduknya sendiri oleh karena mendengar firman Tuhan. Tidak ada indikasi bahwa ia mengadakan gerakan peperangn rohani dan gerakan doa seperti yang dimaksud oleh gerakan transformasi. Sydney Page, telah melakukan penelitian yang ekstensif tentang Iblis dalam Alkitab, namun ia tidak menyinggung apa pun mengenai penyerangan Yesus terhadap Iblis di padang gurun. Sebaliknya ia menekankan bahwa kedatangan Yesus merupakan inisiatif Roh Kudus, atas kehendak Allah. Dengan demikian pencobaan dari Setan dalam peristiwa di padang gurun termasuk dalam rencana Allah dan implikasinya adalah Setan berada di 
bawah kendali Allah. ${ }^{20}$ Rasul Paulus mengatakan bahwa kita berperang bukan dengan darah dan daging melainkan dengan kekuatan-kekuatan di udara (Ef 6:10-12). Jika teks tersebut diindikasikan sebagai perintah untuk mengadakan peperangan rohani seperti yang dimaksud oleh gerakan transformasi, maka hal itu adalah sesuatu yang bertentangan dengan maksud dan tujuan penulis itu sendiri. Teks tersebut tidak mengindikasikan bahwa Paulus meminta para pembacanya untuk melakukan pemetaan spiritual melainkan agar bersenjatakan seluruh perlengkapan senjata Allah (Ef 6:13-20) melawan kuasa-kuasa sijahat. Ada fakta yang menarik ketika Rasul Paulus mengunjungi kuil di Athena, ia sama sekali tak menceritakan mengenai berdoa dengan cara mengelilingi kuil tersebut (prayer-walking) atau melakukan pemetaan spiritual dan mengumpulkan pendoa syafaat, melainkan ia menginjili mereka dimana mereka berada (Kis 17:16-34).

Ajaran Signs \& Wonder (Wimber) yang menyebut bahwa keselamatan dalam penebusan Kristus belum lengkap dan harus diisi dengan bukti tanda dan mujizat, demikian juga Otis menyebut bahwa peran Tuhan Yesus di kayu salib tidak berarti kecuali manusia melalui para rasul barunya mampu memetakan dunia spiritual dan memerangi roh-roh teritorial dengan kuasa doa syafaat dan puasa manusiawi. Konsep mengenai doa berjalan (prayer-walk on sight with insight) dengan menara doanya untuk menguduskan suatu kawasan seperti yang dilakukan di hari Kenaikan Yesus di Jakarta beberapa waktu lalu, dan Gerakan Doa Nasional pada bulan Mei 2012 lalu, maupun doa memberkati suku-suku atau kawasan tertentu, jelas menekankan ajaran Words of Faith yang menjadikan doa lebih semacam "mantra" daripada keseriusan dalam memberitakan Injil dan menyuarakan dan mengupayakan pembaruan sosial, serta bukan sebagai alat dialog dengan Tuhan dan Tuhan yang mendengar yang akan memberikan jawaban-Nya.

\section{$\underline{\text { Rekonstruksi Doktrin Transformasi }}$}

Kita harus menghargai usaha-usaha untuk membangkitkan kerinduan yang mendalam agar terjadinya transformasi bagi masyarakat dengan melakukan berbagai cara yang telah dipaparkan sebelumnya, namun perlu di tegaskan bahwa transformasi tidak terjadi karena orang Kristen hanya sekedar menekankan sikap pragmatis yang dikemas dalam bentukbentuk gerakan doa dan "kumpul-kumpul rohani." Berkaitan dengan hal itu

${ }^{20}$ Sydney Page, Power Of Evil: A Biblical Study of Satan and Demons (Grand Rapids, Michigan: Baker Book House, 1995), 91 
Piper memaparkan bahwa: "Jika Injil Kristus yang mulia yang berpusat pada Allah tidak mempenetrasi suatu kelompok masyarakat dan melahirkan Gereja-gereja yang menyembah, memelihara iman, dan mengabarkan Injil, maka tidak ada sedikit pun harapan bagi transformasi." 21 Yang perlu ditransformasi adalah dimulai dari Gereja atau umat Kristen (Rm 12:1-2), dan bukannya transformasi Indonesia dengan kekuatan doa semata (bukan menolak pentingnya doa dalam kehidupan Kristen, doa bukanlah bahasa klise yang artifisial), serta upaya memobilisasi massa untuk show force dan pengaruh kekuatan kekristenan, melainkan kebersamaan di doa sekaligus mewujudkan dalam tindakan kebersamaan mensejahterakan masyarakat.

Doktrin seharusnya mengarahkan dan memotivasi Gereja dalam upaya menciptakan harmonisasi dalam kehidupan praktis umat. Doktrin harus langsung berhubungan dengan kehidupan prakatis, penderitaan manusia, pertanyaan arti hidup, ikut tersinggung terhadap penindasan, menggali dan menemukan kemungkinan-kemungkinan, serta mencari jawaban dan jalan keluar dari persoalan-persoalan hidup umat Allah khususnya dan masyarakat umumnya. Artinya antara memahami Gereja sebagai karya Allah dengan perannya sebagai agen transformasi adalah suatu keharmonisan hidup, tidak ada pertentangan pada keduanya. Berkaitan dengan hal itu, Vanhoozer mengemukakan bahwa, doktrin membantu Gereja memahami di mana Gereja telah dilemparkan dan peran apa yang harus dimainkan di sana... Doktrin yang kuat-ajaran yang berkuasa-vital bagi kehidupan Gereja, teologi itu bagi kehidupan dunia. ${ }^{22}$ Pada satu sisi, doktrin yang menguatkan peran Gereja harus dirumuskan dan berakar pada kebenaran penyataan Allah di dalam Alkitab. Namun pada sisi lain, doktrin harus langsung berhubungan dengan kehidupan prkatis, penderitaan manusia, pertanyaan arti hidup, ikut tersinggung terhadap penindasan, menggali dan menemukan kemungkinankemungkinan, serta mencari jawaban dan solusi persoalan-persoalan hidup umat Allah khususnya dan masyarakat umumnya. Perlu dipahami bersama bahwa doktrin Gereja bukanlah firman Tuhan yang tidak dapat diubah, melainkan dalam perannya di dunia Gereja perlu mempertimbangkan doktrin selaras dan mampu memotivasi kehidupan orang Kristen untuk menyatakan kasih Allah. 2008), 109

${ }^{21}$ John Piper, Gairah Allah Bagi Kemuliaan-Nya. Terj. (Surabaya: Momentum,

${ }^{22}$ Kevin J. Vanhoozer, Drama Doktrin: Suatu pendekatan Kanonik-Linguistik pada theologi Kristen. Terj. (Surabaya: Momentum, 2011), 4 


\section{Keutuhan Transformasi Kristen}

Transformasi Kristen hendaknya dirumuskan dalam upaya membangun doktrin di dalam Kristus dengan melibatkan perubahan cara hidup, bukan hanya sebuah sistem kepercayaan atau mobilisasi massa Kristen dan bahkan bukanlah merupakan slogan-slogan yang membangkitkan fanatisme belaka. Hal ini berarti bahwa doktrin transformasi merupakan motivasi penting dalam upaya menerangkan segala sesuatu yang berkaitan dengan peran Gereja menjadi berkat di dalam dunia, bagi orang-orang percaya dan yang tidak percaya seperti yang dikemukakan oleh Roeroe sdebagai berikut:

Jadi pokok-pokok pikiran tentang tugas dan panggilan Gereja/jemaat itu kita ringkaskan demikian: untuk "menjadi berkat bagi segala kaum" mulai dari hal: mengolah, memelihara dan membina bumi ini agar menjadi tempat kehidupan yang layak bagi manusia dan bagi semua (bnd. Kej 2, 15), menguatkan yang lemah lesu dan menguatkan lutut yang goyah, memberikan pengharapan bagi yang takut, menyembuhkan yang sakit hingga membangkitkan yang mati. $^{23}$

Berkaitan dengan hal itu, Karman mengemukakan bahwa ada kesinambungan antara Israel sebagai umat Allah dengan Gereja bahwa, "kesinambungan itu terlihat sedikitnya dari kesamaan peran keduanya di dalam dunia sebagai terang dunia dan saksi Allah yang hidup. Umat Israel menjadi terang bagi bangsa-bangsa lain (Yes 42:6) dan umat Kristen juga berperan sebagai terang dunia (Mat 5:14-16) mengikuti jejak Yesus yang adalah Terang Dunia (Yoh 8:2; bd 9:5)." ${ }^{24}$ Dimensi dogma di dalam Gereja dengan eksistensi kehidupan di dunia bukanlah merupakan dua hal yang berjalan terpisah satu sama lain, melainkan suatu keutuhan. Kedua wilayah tersebut terkait amat erat satu dengan lainnya. Berkaitan dengan hal itu, Roeroe mengemukakan bahwa bahwa di dalam PL peran orang percaya, khususnya Tua-Tua Israel mencakup aspek rohani, maupun untuk yang sering dianggap soal-soal duniawi. ${ }^{25}$

${ }^{23}$ W.A. Roeroe, Pokok-Pokok Pikiran Tentang Gereja Untuk Perumusan Tata Gereja [Ekklesiologi Baru], (Tomohon: GMIM, 2005), 11-12

24 Yongky Karman, Bunga Rampai Teologi Perjanjian Lama (Jakarta: BPK Gunung Mulia, 2004), 120

${ }^{25}$ W.A. Roeroe, Peranan Para Tua-Tua dalam Naskah-Naskah Perjanjian Lama (Tomohon: UKIT-Press dan LETAK, 2008), 18-19. Para Tua-tua melaksanakan tanggungjawab dan peranannya merangkumi bidang memimpin kehidupan bersama sebagai persekutuan dan menjaga agar hubungan-hubungan perorangan lestari; menanggulangi permasalahan-permasalahan keluarga besar, marga, suku serta pemukiman 
Dalam PB, penulis Injil Matius mengemukakan hal yang sama (walaupun dengan bahasa yang berbeda) ketika mencatat pernyataan Yesus yang mengecam para ahli-ahli Turat dan orang-orang Farisi, "Celakalah kamu, hai ahli-ahli Taurat dan orang-orang Farisi, hai kamu orang-orang munafik, sebab kamu menelan rumah janda-janda sedang kamu mengelabui mata orang dengan doa yang panjang-panjang. Sebab itu kamu pasti akan menerima hukuman yang lebih berat (Mat 23:14). Artinya, pernyataan Yesus tidak memisahkan antara kepercayaan seseorang dengan kehidupan dalam masyarakat. Yesus menghendaki adanya kesatuan antara aspek ibadah kepada Allah dengan sikap konkret dalam kehidupan sehari-hari. Tidak ada pemisahan antara dogma sebagai formalitas di dalam Gereja dengan tindakan konkret sebagai peran Gereja di dalam dunia. Transformasi memberi tempat untuk mengklarifikasi tersendiri isi dari iman Kristen untuk memampukan Gereja dalam komunitas Kristen menjelaskan tentang apa yang dipercayai di dalam kesaksian bagi dunia (terkait di dalamnya mengenai hidup dalam kebenaran dan memperjuangkan keadilan dan usaha memperbaiki kerusakan sosial). Hal itu juga berarti bahwa transformasi menyelidiki isi dari teologi Kristen untuk tujuan kehidupan praktis agar tepat dan efektif dikomunikasikan dalam tiap-tiap keadaan sosial, bahasa, dan latarbelakang kultur. Hal inilah yang menjadi perhatian dari Gereja seperti yang dikemukakan oleh Karl Barth bahwa, "dogmatics as such does not ask what the apostles and prophets said but what we must say on the basis of the apostles and prophets. ${ }^{" 26}$ Doktrin, jauh dari teori yang abstrak, sebenarnya merupakan bahan kehidupan nyata. Kehidupan nyata terletak di jalan Yesus Kristus, dan tujuan doktrin adalah membimbing kita tepat di jalan ini. ${ }^{27}$ Gereja sebagai saksi Kerajaan Allah, harus mendemonstrasikan totalitas Kerajaan tersebut. Totalitas Kerajaan Allah merupakan mandat Yesus kepada Gereja-Nya. Mandat itu adalah mandat penginjilan dan sekaligus juga mandat pelayanan sosial. Gereja hidup dalam dua dimensi: "di dalam Kristus" dan "di dalam dunia" (Yoh 15:1-6; 17:13-18). Gereja perlu menekankan ibadah dan pembangunan masyarakat, pekabaran Injil dan kepedulian sosial. Gereja perlu

dan perkotaan, sebagai penegak hukum dan membela keadilan dalam keputusan-keputusan pengadilan dan kehakiman, mereka bertanggungjawab atas ketertiban, keamanan dan pertahanan-keamanan-kemiliteran, atas pembebasan dari penindasan, atas masalah kecukupan makanan dan minuman, masalah ibadah-persembahan dan doa syafaat, masalah politik kedalam dan keluar persekutuan umat.

26 Karl Barth, Church Dogmatics. Trans. G. W. Bromiley, second edition. (Edinburgh: T. \& T. Clark, 1975), 16

${ }^{27}$ Vanhoozer, Drama Doktrin ..., 2 
menyatakan kasih dan keadilan Tuhan, dimulai dari konteks Gereja sendiri serta perbuatannya bagi masyarakat tanpa maksud-maksud tersembunyi. Pelayanan Gereja dalam masyarakat adalah salah satu cara untuk menyatakan kasih Tuhan di dalam ketulusan dan kejujuran. Berkaitan dengan hal itu, Schaeffer mengemukakan bahwa, The point is that it is possible to be a Christian without showing the mark; but if we expect nonChristian to know that we are Christians, we must show the mark. ${ }^{28}$

Keutuhan transformasi seharusnya muncul bukan dari teori-teori spekulatif tetapi dari praktik-praktik inti berita firman Tuhan serta pengalaman kehidupan sehari-hari yang membentuk kehidupan dan identitas Gereja dan orang-orang Kristen secara terus-menerus, sehingga berupaya sedemikian rupa memengaruhi jemaat dan masyarakat umumnya.

\section{KESIMPULAN}

Fenomena Gerakan Transformasi yang berkembang di Indonesia, satu sisi harus diberi apresiasi. Upaya yang dilakukan dalam beberapa kegiatan akbar sebagai wujud ingin mempersatukan lembaga-lembaga Gereja dan gerejawi dalam kegiatan persekutuan dan doa bersama, serta berkolaborasi antara tokoh-tokoh nasional dengan internasional telah memberi pengaruh yang cukup signifikan, dan bahkan bisa disebutkan sebagai suatu kegiatan yang fenomenal di Indonesia. Namun demikian, harus juga dicermati kemana arah transformasi yang diinginkan. Apakah sebatas hanya untuk memperlihatkan bahwa lembaga-lembaga Gereja dan Gerejawi dapat berkumpul bersama-sama, wujud dari kesatuan, atau untuk memperlihatkan bahwa Tuhan berkarya meningkatkan jumlah orang-orang Kristen? Jika bisa disebutkan dengan bahasa iman. Atau hanya sebatas suatu kegiatan Kristen rohani yang didukung oleh sebagian dari tokohtokoh Kristen internasional atau dengan bahasa "kumpul-kumpul bareng"? Atau bisa jadi kegiatan tersebut justru tidak rohani (berbagai perspektif dapat berkembang untuk terminologi istilah rohani, bahkan penyimpangannya). Kemanakah arah yang mau dibawa oleh tokoh-tokoh Kristen untuk transformasi di Indonesia? Jika tanpa merumuskan secara sistematis dan pengakuan bersama akan apa yang dilakukan di dalam Gereja serta di luar Gereja.

${ }^{28}$ Francis A. Schaeffer, The complete works of Francis A. Schaeffer A Christian Worldview, Volume Four: A Christian View of the Church (Westchester: Crossway Books, 1982), 184 
PL dan PB mendorong manusia untuk memperbaiki dunia. Allah, hakim-hakim, para nabi, raja-raja, dan Yesus melakukan upaya yang terus menerus dalam memberitakan suara transformasi; keadilan dan kebenaran, menaati hukum, mengkritisi ketidakadilan dan ketidakbenaran, membela hak-hak orang yang miskin, lemah, yang ditindas, serta mengupayakan kesejahteraan bangsa. Keberadaan dunia ini pada dasarnya tidak jahat, melainkan baik karena diciptakan Tuhan. Tentu ciptaan yang baik itu telah dinodai oleh dosa. Manusia telah memanipulasi dan merampas kebaikan dan kasih yang benar. Namun ciptaan itu masih berharga dan perlu diperbaiki di dalam penebusan Kristus. Gereja atau orang Kristen tidak berhak menolak keberadaan dunia yang merupakan ciptaan Allah di dalam Kristus (Kol 1:15-16), melainkan ikut serta memberi solusi terhadap persoalan-persoalan yang dihadapi oleh dunia. Dunia adalah dunia Allah di mana Gereja hidup dan tinggal menjadi berkat.

Gerakan Transformasi yang menekankan mobilisasi doa massa bisa jadi hanya mengarah kepada pencapaian kesatuan Gereja-gereja, dan upaya damai sejahtera (feel good theology) yang akan dialami secara transformatif di Indonesia. Hal itu bisa saja menjadi gerakan yang lebih mirip ambisi doa dan perilaku "nabi-nabi" yang dikritik oleh beberapa nabi dan Tuhan Yesus. Jika Gereja tidak menyuarakan kebenaran dengan mengingatkan pemerintah, para politikus, para tokoh agama, para pengusaha secara khusus pemimpin dan pengusaha Kristen yang sarat dengan prilaku KKN dan mengabaikan hukum serta tidak adanya upaya yang sistematis dari pihak Gereja untuk memperbaiki keadaan sosial, maka doa-doa orang Kristen bisa jadi hanya sebatas artifisial belaka. Artinya doa-doa yang diungkapkan dan "kumpul-kumpul bareng" tidak menjadi edukasi bagi orang-orang Kristen, dapat dilepaskan dari prilaku hidup benar, serta terlepas dari takut akan Tuhan dan mengabaikan hukum yang merupakan prasyarat kesejahteraan bangsa dan Negara. Jika di dalam Gereja dan Yayasan Kristen serta partai politik sendiri menyimpan kebusukan dan mempertontonkan perilaku ketidakadilan dan ketamakan akan kekuasaan dan harta serta tidak memperdulikan kesejahteraan orang lain, maka transformasi seperti apa yang dapat kita harapkan?

Pada satu sisi gerakan transformasi yang telah dikemukakan di atas harus dihargai dalam upaya untuk kesatuan Gereja-gereja Tuhan di Indonesia, serta upaya mengembangkan spirit kerjasama antar orang-orang Kristen dalam persekutuan. Namun pada sisi lain, gerakan tersebut menyisakan persoalan-persoalan yang tidak kalah merisaukan, sebab spirit transformasi yang ditawarkan adalah dalam rangka mobilisasi masa untuk menghacurkan kuasa kegelapan bukannya upaya sistematis dalam 
menyuarakan pertobatan dan memberlakukan keadilan serta upaya menanggulangi kemiskinan yang merupakan salah satu isu utama di Indonesia, demi kesejahteraan masyarakat Indonesia. Gereja dan umat Tuhan membutuhkan keseriusan dalam upaya transformasi di dalam Kristus, merumuskan dan mengajar-ajarkan dogma dalam ibadah dan keharmonisannya dengan kehidupan praktis sebagai tanggungjawab dan ketaatan kepada Allah dan sesama. Hal itu berarti Gereja akan bergumul dengan isu-isu yang berkembang dan kompleks pada eranya dan mungkin sekali sebagai suatu persiapan kedepan dalam kerangka mempersiapkan yang pada umumnya disebut tanggungjawab pelayan menjadi berkat bagi bangsa-bangsa. 